\title{
Pengambilan Keputusan Pasangan Usia Subur ( PUS ) Dalam Penggunaan Alat Kontrasepsi Pada Program Keluarga Berencana ( KB )
}

\author{
Winda Sari Sinaga \\ Windasarisng1701@gmail.com
}

\section{Latar Belakang}

Dalam dunia kerja perawat akan sering menjumpai beragam kasus, baik dari kasus yang sederhana sampai kasus yang rumit. Dikarenakan hal itu, perawat dituntut untuk mampu berpikir kritis dan mampu memberi tanggapan dan respon yang cepat. Berpikir kritis merupakan suatu kemampuan yang wajib dimiliki oleh seorang perawat sebagai kompetensi dasar bagi perawat untuk menginterpretasi, menganalisis dan mengevaluasi dalam melakukan tindakan asuhan keperawatan kepada pasien. Berpikir kritis memiliki kaitan yang dekat dengan proses pengambilan keputusan seorang perawat dalam melakukan penilaian klinis yang nantinya akan menjadi penentu tindakan ataupun Asuhan Keperawatan yang akan diberikan Perawat kepada pasien. Pengambilan keputusan merupakan salah satu tindakan dan upaya yang dapat dilakukan perawat untuk memecahkan permasalahan, salah satunya adalah pengambilan keputusan untuk mencegah laju pertumbuhan jumlah penduduk yang tinggi melalui penggunaan alat kontrasepsi dan program Keluarga Berencana ( KB ).

Penggunaan alat kontrasepsi dalam program Keluarga Berencana ( KB ) bertujuan agar terkendalinya pertumbuhan penduduk dan diikuti meningkatnya taraf hidup dan kesejahteraan penduduk Indonesia. Pengambilan keputusan penggunaan alat kontrasepsi dalam keluarga merupakan Salah satu hal yang mendukung pelaksanaan program pemerintah dalam mengatasi masalah kependudukan di Indonesia. Oleh sebab itu, pengambilan keputusan yang tepat dalam penggunaan alat kontrasepsi akan membawa pada keberlanjutan program Keluarga Berencana. Indonesia sebagai salah satu negara berkembang yang menghadapi masalah kependudukan yaitu laju pertumbuhan jumlah penduduk yang relatif tinggi. Menurut World Population Data Sheet 2013, Indonesia menjadi negara kelima di dunia dengan jumlah penduduk sebanyak 249 juta. Dan berdasarkan data Badan Pusat Statistik, jumlah penduduk Indonesia diperkirakan akan meningkat setiap tahunnya .

Indonesia memiliki kebijakan untuk menekan tingginya laju pertumbuhan penduduk Indonesia melalui program KB. Keluarga Berencana adalah upaya peningkatan kepedulian peran serta masyarakat melalui pendewasaan usia perkawinan (PUP), pengaturan kelahiran, pembinaan 
ketahanan keluarga, peningkatan kesejahteraan keluarga kecil, bahagia dan sejahtera. Program Keluarga Berencana ( KB ), menjadi salah satu upaya yang dilakukan Indonesia dalam mengendalikan beberapa masalah yakni jumlah pertumbuhan penduduk yang tinggi, masalah kemiskinan dan mengurangi kematian ibu melahirkan. Masalah kemiskinan terjadi karena besarnya jumlah penduduk yang tidak diimbang dengan pemenuhan kebutuhan hidup yang layak bagi keluarga. Program Keluarga Berencana juga menjadi solusi untuk mengurangi angka kematian ibu melahirkan dengan kondisi 4T, yakni terlalu muda melahirkan, terlalu sering melahirkan, terlalu dekat jarak melahirkan dan terlalu tua melahirkan.

Pengambilan keputusan penggunaan alat kontrasepsi dalam keluarga mendukung pelaksanaan program pemerintah dalam mengatasi masalah kependudukan di Indonesia. Melalui program ini, diharapkan akan membantu pasangan suami-istri untuk menghindari kehamilan yang tidak diinginkan, mengatur interval di antara kehamilan, menentukan jumlah anak dalam keluarga. Sehingga kedepannya akan terus terbentuk keluarga kecil yang berkualitas, sejahtera, maju dan mandiri yang juga mencegah terjadinya masalah kemiskinan.

Salah satu kunci kesuksesan program KB adalah partisipasi individu baik istri maupun suami dalam pemakaian kontrasepsi. Pemilihan penggunaan alat kontrasepsi dalam rumah tangga memerlukan pertimbangan terkait memilih cara atau metode mana yang tepat dan baik untuk digunakan. Akan muncul banyak faktor-faktor yang mempengaruhi pengambilan keputusan contohnya kekhawatiran terhadap bahaya kesehatan, adanya ketidakcocokan dengan alat kontrasepsi serta pemahaman yang berbeda antara suami dengan istri tentang Keluarga Berencana yang besar kemungkinan memunculkan keputusan yang berbeda dan mempengaruhi hasil keputusan. Dari permasalahan tersebut, akan menuntut suatu solusi yang menjadi keputusan pihak bersangkutan, di mana pengambilan keputusan dalam keluarga atau pasangan usia subur dapat dilakukan oleh siapa saja, baik oleh suami, istri ataupun orang tua tergantung sikap keluarga dalam menyikapi permasalahan.

\section{Metode}

Metode yang digunakan oleh penulis dalam jurnal ini adalah Literature review, dengan cara membaca, menganalisis kajian textbook, e-book, buku pedoman terkait, tesis dan jurnal online yang relavan dengan pokok bahasan yakni pengambilan keputusan dalam penggunaan alat kontrasepsi pada pasangan usia subur. Adapun jurnal dan referensi yang digunakan pada literature review ini dengan tahun terbit paling lama tahun 2012, dengan jumlah minimal yaitu 10 referensi. 


\section{Hasil}

Berdasarkan hasil pencarian literatur, didapati untuk pengambilan keputusan dalam pemakaian kontrasepsi oleh pasangan usia subur dipengaruhi oleh beberapa faktor. Dari jurnal yang yang telah dibaca yaitu Jurnal Populasi Vol. 23, No. 1, 2015, menurut hasil jurnal tersebut dapat disimpulkan bahwa adanya kaitan karakteristik individu yang berpengaruh terhadap pengambilan keputusan dalam penggunaan alat kontrasepsi. Pengambilan keputusan pasangan usia subur ( PUS ) dalam penggunaan alat kontrasepsi dipengaruhi oleh beberapa faktor yang sangat signifikan yaitu; karakteristik rumah tangga, pengetahuan tentang Keluarga Berencana (KB) dan faktor pengambilan keputusan dalam keluarga.

Dalam jurnal yang yang telah dibaca yaitu Jurnal Sosiologi Universitas Negeri Malang Vol. 9, No.1, 2016, menurut hasil jurnal tersebut dapat disimpulkan bahwa terdapat hubungan yang signifikan antara konseling Keluarga Berencana dengan pengambilan keputusan pasangan usia subur dalam menggunakan alat kontrasepsi.

Dalam jurnal yang yang telah dibaca yaitu Jurnal 100 Bidan Prada: Jurnal Ilmiah Kebidanan, Vol. 5, No. 2, 2014, menurut hasil jurnal tersebut dapat disimpulkan bahwa pengetahuan responden tentang efek samping kontrasepsi sebagian besar dalam katagori cukup $(68,85 \%)$ dan kurang $(14,75 \%)$. Hal ini menjadi salah satu faktor yang mempengaruhi wanita usia subur ( WUS ) untuk tidak menggunakan alat kontrasepsi.

Maka dari hasil perbandingan jurnal-jurnal tersebut, dapat disimpulkan bahwa pembuatan keputusan pasangan usia subur dalam penggunaan alat kontrasepsi dipengaruhi oleh tingkat pengetahuan tentang program $\mathrm{KB}$ dan informasi mengenai alat kontrasepsi sangat mempengaruhi keputusan akhir yang akan dibuat. Dari hasil jurnal-jurnal tersebut dapat disimpulkan bahwa tingkat pengetahuan tentang alat kontrasepsi dan program Keluarga Berencana ( $\mathrm{KB}$ ), menjadi faktor yang sangat mempengaruhi pengambilan keputusan pasangan usia subur dalam menggunakan alat kontrasepsi. Factor Pengetahuan tentang keluarga berencana dan penggunaan alat kontrasepsi pada pasangan usia subur dipengaruhi lagi oleh beberapa aspek seperti dorongan keputusan dari suami dan campur tangan keluarga dalam pengambilan keputusan, yang didukung dengan dasar pengetahuan keluarga muda mengenai program KB dan pemasangan alat kontrasepsi setelah melahirkan. 


\section{Pembahasan}

Hubungan Konseling KB dengan Pengambilan Keputusan PUS dalam Penggunaan Alat Kontrasepsi.

Konseling KB meliputi hal-hal perpindahan, pemberian pengetahuan tentang model dan cara kerja kontrasepsi yang memungkinkan pasien mempunyai pilihan informasi dan meningkatkan kepatuhan penggunaan metode kontrasepsi efektif. Informasi yang lengkap dan cukup memberikan keleluasaan nagi keluarga muda dalam memutuskan pilihan kontrasepsi yang digunakan sehingga menurunkan angka dropout akseptor KB, menurunkan kehamilan yang tidak diinginkan dan meningkatkan konsistensi dan ketepatan penggunaan alat kontrasepsi.

Selama pemberian konseling, pelayanan kesehatan diharapkan mampu memberikan pengetahuan tentang model kontrasepsi yang tepat, cara kerja metode kontrasepsi terpilih. Dengan demikian, peran konselor dalam konseling KB adalah memastikan pilihan informasi kontrasepsi sudah tepat, membantu klien mempertimbangkan semua aspek masalah untuk pilihan yang cocok dan terbaik.

Konseling mengenai program KB, dapat mengubah perilaku pemilihan kontrasepsi. Dimana diharapkan sesuai dengan prinsip konseling, konseling menerapkan komunikasi yang diawali dengan interaksi yang saling percaya antara konselor dengan klien. Pilihan metode KB relatif mudah, tetapi upaya penguatan kebiasaan penggunaan metode terpilih perlu dilakukan secara berkesinambungan.

Konseling merupakan aspek yang sangat penting dalam pelayanan KB dan kesehatan reproduksi. Dengan adanya konseling KB, menjadi factor yang meningkatkan pengambilan keputusan dalam penggunaan kontrasepsi. Dengan adanya konseling berarti, adanya petugas yang membantu klien dalam memilih dan memutuskan jenis kontrasepsi yang akan digunakan sesuai dengan pilihannya.

Hubungan konseling KB dengan pembuatan keputusan penggunaan alat kontrasepsi pada hasil penelitian jurnal tersebut menyatakan Terdapat hubungan yang sangat signifikan antara keduanya yang membantu responden keluar dari berbagai pilihan dan alternatif masalah kesehatan reproduksi dan keluarga berencana ( $\mathrm{KB}$ ), dengan rutin menjalani konseling program KB membantu PUS untuk menggunakan metode KB secara konsisten, rutin dan sukses. Dapat ditarik kesimpulan bahwa seseorang yang mempunyai pengetahuan yang baik mengenai KB akan menyadari betapa pentingnya manfaat program KB. Dengan mengikuti 
konseling KB, mempengaruhi keputusan yang akan diambil dalam memilih alat kontrasepsi. Di dimana hal ini menuntun keputusan akhir yang tepat.

Karakteristik rumah tangga dan dan faktor pengambilan keputusan dalam keluarga.

Karakteristik rumah tangga dilihat dari pendapatan dan jumlah anak yang dimiliki. Jumlah anak menjadi pertimbangan dalam pengambilan keputusan penggunaan kontrasepsi. Bagi responden yang baru mempunyai satu anak alasan tidak menggunakan kontrasepsi karena ingin menambah anak lagi. Sedangkan bagi responden yang lain alasan ingin menambah anak karena alasan jenis kelamin anak. Bagi responden yang mempunyai anak perempuan ingin mempunyai anak laki-laki. Jumlah anak juga dapat dipengaruhi oleh faktor kebudayaan, yang mana menganggap anak laki-laki lebih bernilai dari anak perempuan. Hal ini mengkibatkan pasangan suami istri berusaha untuk menambah jumlah anak mereka jika belum mendapatkan anak lakilaki, karna dianggap penting mengenai pewaris dan pelanjut keturunan suku atau Marga, individu dengan budaya seperti ini, biasanya lebih sulit untuk mau mengikuti program Keluarga Berencana.

Karakteristik rumah tangga juga didukung dengan faktor pengambilan keputusan dalam keluarga, di mana penentuan penggunaan kontrasepsi oleh istri lebih banyak mendapatkan campur tangan dari suami. Dilihat dari besarnya prosentase dukungan keikutsertaan suami dalam kelas konseling program Keluarga Berencana.

Namun angka pengambilan keputusan memakai kontrasepsi langsung diambil alih oleh istri, juga tinggi. Di mana penggunaan alat kontrasepsi pada istri biasanya ditentukan langsung oleh istri , atas keinginan pribadi( istri memutuskan sendiri untuk menggunakan alat kontrasepsi ). Mengingat keberadaan istri saat ini yang ikut membantu ekonomi keluarga dengan bekerja, menjadi salah satu faktor penguat penggunaan kontrasepsi oleh keputusan istri secara individu.

Hubungan kurangnya informasi dan pengetahuan mengenai alat kontrasepsi dan program KB pada wanita usia subur ( WUS ).

Kurangnya pengetahuan, pelayanan kesehatan, pendidikan kesehatan reproduksi, kurangnya informasi mengenai Keluarga Berencana dan kurangnya konseling program KB menjadi faktor or wanita usia subur tidak menggunakan alat kontrasepsi. Alasan lain yang diberikan yaitu, 
ketidakpahaman metode dan efek samping kontrasepsi yang menjadi dasar kuat untuk tidak menggunakan alat kontrasepsi ataupun program Keluarga Berencana.

Selain itu ketidakpahaman pasangan usia subur, baik istri maupun suami akan program penggunaan alat kontrasepsi menjadikan alasan untuk tidak menggunakan alat kontrasepsi. Salah satunya contohnya ketidakpahaman kepala keluarga ( suami ) akan tujuan dari program KB sehingga melarang pasangan untuk tidak menggunakan alat kontrasepsi ataupun mengikuti program KB. Alasan yang lain dengan persentase yang cukup tinggi adalah alasan ekonomi, yang menyatakan bahwa penggunaan alat kontrasepsi secara rutin akan mengeluarkan banyak biaya.

\section{Penutup}

Pengambilan keputusan pasangan usia subur dalam penggunaan alat kontrasepsi sangat dipengaruhi oleh faktor pengetahuan pasangan mengenai program Keluarga Berencana. Dimana tingkat pemahaman dan pengetahuan mengenai Keluarga Berencana menjadi faktor terkuat bagi pasangan usia subur ataupun wanita usia subur untuk menggunakan alat kontrasepsi.

Dan tidak dapat dipungkiri bahwa perempuan memiliki peranan yang kuat dalam mengambil keputusan penggunaan alat kontrasepsi. Namun tidak sedikit yang belum dibarengi dengan tingkat pengetahuan yang cukup akan jenis dan kelebihan dari setiap alat kontrasepsi. Dengan begitu perlu diperkuat kegiatan konseling, sosialisasi mengenai program KB agar meningkatkan pengetahuan wanita Indonesia mengenai kesehatan reproduksi dan keluarga berencana. Dengan begitu Itu akan lebih banyak perempuan yang memiliki kebudayaan dan pengetahuan yang cukup mengenai langkah-langkah yang mesti ditempuh apabila mengalami keluhan keluhan sakit yang diakibatkan penggunaan alat kontrasepsi tertentu.

\section{Daftar Pustaka}

Astuti Eni, dan Ratifah. 2014. DESKRIPTIF FAKTOR-FAKTOR YANG MEMPENGARUHI WANITA USIA SUBUR (WUS) TIDAK MENGGUNAKAN ALAT KONTRASEPSI . Jurnal Ilmiah Kebidanan. 5 ( 2 ) : 99-108. 
Manurung Suryani. 2013. Model Pengambilan Keputusan Meningkatkan Akseptor Keluarga Berencana Metode Kontrasepsi Jangka Panjang. Jurnal Kesehatan Masyarakat Nasional 7 ( $11)$ : 483-488.

Anggaunitakiranantika. 2016. PENGAMBILAN KEPUTUSAN KELUARGA MUDA DALAM PROGRAM KELUARGA BERENCANA DI KOTA MALANG. Jurnal Dimensi. 9 (1): 47-54.

Setiadi, dan Iswanto Lilik. 2015. PENGAMBILAN KEPUTUSAN PENGGUNAAN ALAT KONTRASEPSI ISTRI DALAM KELUARGA. Jurnal Populasi. 23 ( 1 ): 20-35.

Mallapiang, Azriful dan Jusriani. 2020. PERAN GENDER DALAM PENGAMBILAN KEPUTUSAN PEMILIHAN METODE KONTRASEPSI DI PUSKESMAS PATTALLASSANG KABUPATEN GOWA TAHUN 2016 . Jurnal Pusat Studi Gender dan Anak UIN Alauddin Makassar Sipakalebbi. 4 (1) : 2889-305.

Kementerian Kesehatan RI. 2014. Pedoman Manajemen Pelayanan Keluarga Berencana. Jakarta : Kementerian Kesehatan.

Haryanto Agus, Hubungan berpikir kritis dan waktu tanggap perawat dengan kualitas asuhan keperawatan Di Instalasi Gawat Darurat Rumah Sakit Islam Surabaya, Tesis , Surakarta : Universitas Sebelas Maret, 2014

Fadhilah, Harahap Wirsma Arif, dan Lestari. 2015. Faktor-faktor yang Behubungan Dengan Waktu Tanggap Pada Pelayanan Kasus Kecelakaan Lalu Lintas di Instalasi Gawat Darurat Rumah Sakit Umum Pusat Dr. M. Djamil Padang tahun 2013. Jurnal Kesehatan Andalas. 4 (1) :195-201.

Deniati, Anugrahwati, dan Suminarti. 2018. PENGARUH BERFIKIR KRITIS TERHADAP KEMAMPUAN PERAWAT PELAKSANA DALAM MELAKUKAN ASUHAN KEPERAWATAN DI RUMAH SAKIT HERMINA BEKASI TAHUN 2016. Jurnal Kesehatan Holistik (The Journal of Holistic Healthcare). 12 ( 1 ) : 21-25.

Nurlisis, dan Anggraeni, W.. 2016. Hubungan Pengetahuan Ibu Dan Dukungan Suami Dengan Pemakaian Kontrasepsi Jangka Panjang Di Wilayah Kerja Puskesmas Rumbai Pesisir. Jurnal Photon. 6(2) : 75-80.

Simamora, R. H. (2019). Menjadi perawat yang: CIH'HUY. Surakarta: Kekata Publisher. 
Simamora, R. H. (2005). Hubungan Persepsi Perawat Pelaksana Terhadap Penerapan Fungsi Pengorganisasian Yang Dilakukan Oleh Kepala Ruangan Dengan Kinerjanya Diruang Rawat Inap RSUD Koja Jakarta Utara (Doctoral dissertation, Tesis FIK UI, Tidak dipublikasikan). 